\title{
The First Report of a Megalocytivirus Infection in Farmed Starry Flounder, Platichthys stellatus, in Korea
}

\author{
Kyoung-Mi Won ${ }^{1}$, Mi Young Cho², Myoung Ae Park², Bo Young Jee², Jeong-In Myeong ${ }^{4}$ and Jin Woo Kim ${ }^{3 *}$ \\ ${ }^{1}$ Southwest Sea Fisheries Research Institute, National Fisheries Research and Development Institute (NFRDI), Yeosu 556-823, Korea \\ ${ }^{2}$ Aquatic Animal Disease Control Division, NFRDI, Busan 619-705, Korea \\ ${ }^{3}$ Pathology Division, NFRDI, Busan 619-705, Korea \\ ${ }^{4}$ Aquaculture Management Division, NFRDI, Busan 619-705, Korea
}

\begin{abstract}
In 2009, a systemic megalocytivirus infection associated with high mortality was detected for the first time in cultured starry flounder Platichthys stellatus in Korea. Diseased starry flounder had pale bodies and gill coloring and enlarged spleens. Histopathological examinations revealed basophilic enlarged cells in various organs of diseased starry flounder. Polymerase chain reaction (PCR) was performed on tissue samples using three published primer sets developed for the red sea bream iridovirus. PCR products were detected for all primer sets, except 1-F/1-R, which are registered by the World Organization for Animal Health (OIE). The part of the gene corresponding to the full open reading frame encoding the viral major capsid protein (MCP) was amplified by PCR. PCR products of approximately $1,581 \mathrm{bp}$ were cloned, and the nucleotide sequences were analyzed phylogenetically. The MCP gene of the starry flounder iridovirus, designated SFIV0909, was identical to that of the turbot reddish body iridovirus (AB166788).
\end{abstract}

Key words: Starry flounder Platichthys stellatus, Red sea bream Iridovirus, Turbot reddish body iridovirus, Major capsid protein gene, Phylogenetic analysis

\section{Introduction}

The starry flounder, Platichthys stellatus, is a cold-water benthic fish belonging to the family Pleuronectidae, order Pleuronectiformes. This species has become a candidate marine flatfish for commercial culture in Korea because it tolerates a wide range of salinity, remains hardy in crowded environments, and exhibits rapid growth. This fish adapts well to indoor industrialized culture, which makes it an ideal alternative fish species for aquaculture in Korea. Many aspects of starry flounder culture have been studied in various fields to increase the commercial viability of this fish, such as the effects of dietary lipid levels on growth (Ding et al., 2010), the morphology of eggs during spawning periods (Bian et al., 2010), and the physiology of acute silver toxicity (Hogstrand et al., 1999). However, very little is known about the diseases of starry flounder.

Members of the family Iridoviridae are an emerging group of viral pathogens that are threatening the aquaculture industry; they have caused large economic losses globally. Iridoviruses are large (approximately 120-350 nm) double-stranded DNA viruses that can infect invertebrates and poikilothermic vertebrates, including insects, fish, amphibians, and reptiles (Williams et al., 2005). The family Iridoviridae comprises five genera, including Iridovirus, Chloriridovirus, Ranavirus, Lymphocytivirus, and Megalocytivirus. Of these, Megalocytivirus is newly defined by the International Committee on Taxonomy of Viruses (ICTV) (Chinchar et al., 2005). In recent
Open Access http://dx.doi.org/10.5657/FAS.2013.0093

This is an Open Access article distributed under the terms of the Creative Commons Attribution Non-Commercial License (http://creativecommons. org/licenses/by-nc/3.0/) which permits unrestricted non-commercial use, distribution, and reproduction in any medium, provided the original work is properly cited. pISSN: 2234-1749 eISSN: 2234-1757
Received 6 September 2012; Revised 14 May 2013

Accepted 29 May 2013

*Corresponding Author

E-mail: jwkim@nfrdi.go.kr 
years, megalocytiviruses have attracted considerable attention because most cause serious systemic diseases in a wide range of economically important freshwater and marine fish species worldwide (Chinchar et al., 2009). At present, known megalocytiviruses include red sea bream Pagrus major iridovirus (red sea bream iridovirus [RSIV]) (Kawakami and Nakajima, 2002), mandarinfish Siniperca chuatsi infectious spleen and kidney necrosis iridovirus (ISKNV) (He et al., 2000), rock sea bream Oplegnathus fasciatus iridovirus (RBIV) (Do et al., 2004), orange spotted grouper Epinethelus coioides iridovirus (Lü et al., 2005), and turbot Scophthalmus maxius reddish body iridovirus (TRBIV) (Shi et al., 2010).

In 2009, a disease outbreak occurred in starry flounder farms in Gyeongsangnam-do, Korea, and caused mortality rates of up to $60 \%$. During biopsies of diseased fish, enlarged cells were observed in stamp samples from enlarged spleens, which is suggestive of RSIV disease. In addition, we attempted to detect portions of the iridovirus genome in the spleens and kidneys of diseased fish using PCR, as recommended by the World Organization for Animal Health (OIE) (World Organization of Animal Health, 2009); positive results were obtained only using the primer set 4-F/4-R, and not $1-\mathrm{F} / 1-\mathrm{R}$. This is the first study of iridovirus infection of farmed starry flounder and included taxonomical and histopathological analyses.

\section{Materials and Methods}

\section{Infected fish}

Diseased and healthy starry flounder were collected in September 2009 from a farm located in Gyeongsangnam-do, Korea. Mean fish weight was $22 \mathrm{~g}$. The fish were transported with aeration to a laboratory at the Aquatic Animal Disease Control Division, National Fisheries Research and Development Institute, Busan, Korea, and were alive before examination. Affected fish were lethargic and had reduced appetite, pale body color, enlarged abdomen, and protruding eyes. Key internal characteristics of diseased fish included extremely enlarged spleen and kidney, and pale gills and/or liver.

After sampling some diseased starry flounder, the remaining fish were sacrificed and facilities were disinfected with sodium hypochlorite.

\section{Viral DNA extraction and polymerase chain reac- tion}

Total DNA was extracted from approximately $50 \mathrm{mg}$ of spleen and kidney tissue from diseased starry flounder using a high-purity PCR template preparation kit (Roche, Indianapolis, IN, USA). PCR product quality and concentrations were determined by agarose gel electrophoresis and using a spectrophotometer (NanoVue; GE Healthcare, Little Chalfont, UK).

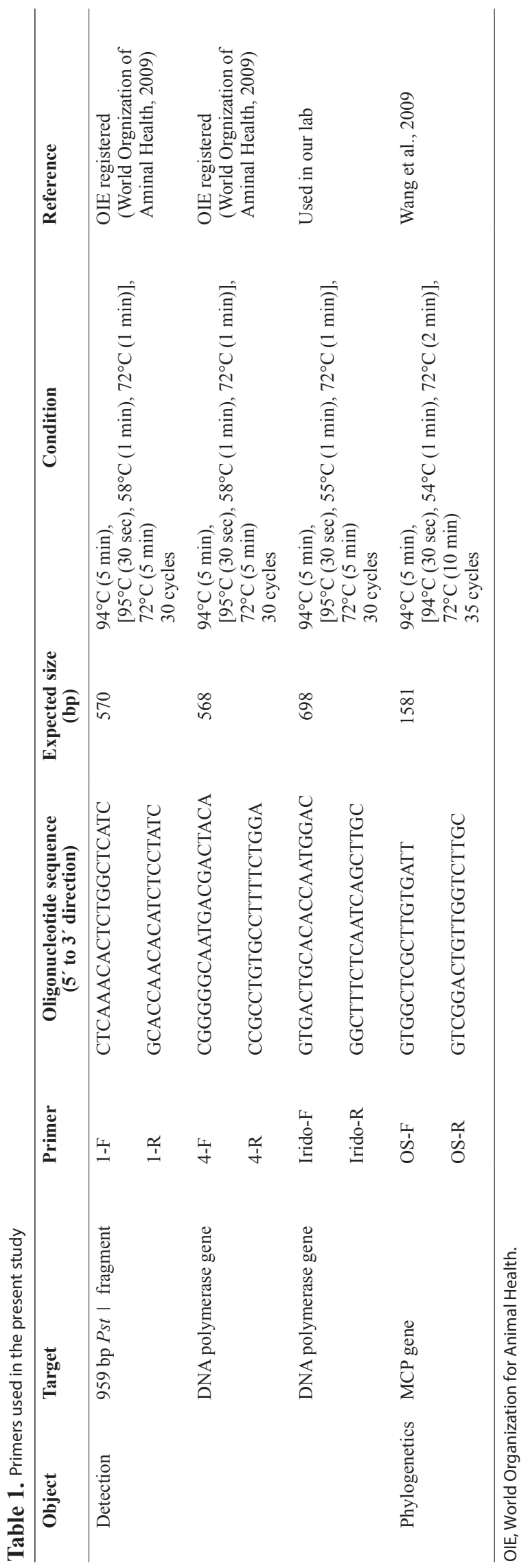




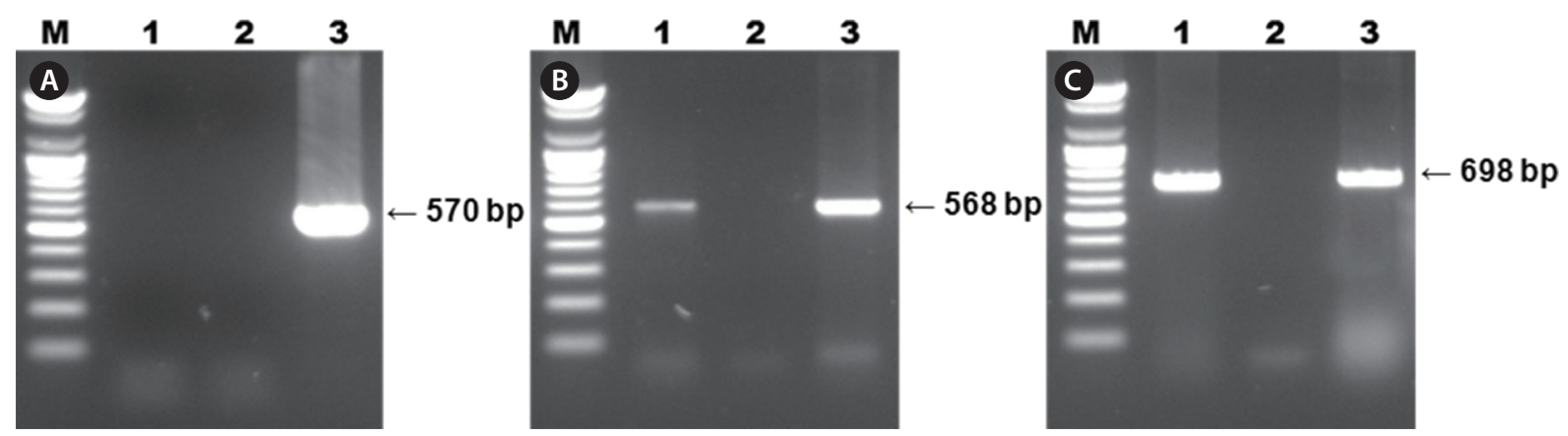

Fig. 1. Detection of starry flounder iridovirus from the spleen of diseased starry flounder by $P C R$ on various primer sets, 1-F/1-R (A), 4-F/4-R (B), and IridoF/lrido-R (C). Lanes: M, molecular marker; 1, spleen of diseased starry flounder; 2 , negative control without template; 3 , positive control (red sea bream iridovirus).

For diagnosis of RSIV, three primer sets were synthesized for use in PCR assays. Two primer sets, $1 \mathrm{~F} / 1 \mathrm{R}$ and $4 \mathrm{~F} / 4 \mathrm{R}$, were designed by Kurita and were registered in the list of the OIE (World Organization of Animal Health, 2009). The other primer set, IridoF/IridoR, was routinely used in our laboratory to detect RSIV. For the phylogenetic analysis, the OSF/OSR primer set was used (Table 1). Extracted genomic DNA (100 ng) was PCR amplified using Hot Start ExTaq polymerase (TaKaRa, Tokyo, Japan), using the conditions for the individual primer sets.

\section{Sequencing and phylogenetic analysis of the major capsid protein (MCP) gene}

The PCR products were purified using a gel purification kit (GeneAll, Seoul, Korea). The purified products were cloned with a TOPO-TA cloning kit (Invitrogen, Carlsbad, CA, USA) and subjected to nucleotide sequence analysis using an $\mathrm{ABI}$ PRISM 3730 XL DNA Analyzer with a BigDye terminator kit (Applied Biosystems, Inc., Foster City, CA, USA). Nucleotide sequences obtained from individual sequencing reactions were assembled using the Data Collection and Sequence Analysis software (Applied Biosystems, Inc.).

Sequences acquired in this study were compared with those from other megalocytiviruses that are available in the GenBank/EMBL nucleotide database; alignment was performed using the software Genetyx v. 7 (Genetyx, Tokyo, Japan). Phylogenetic trees were constructed by neighbor-joining analysis with the software MEGA v. 4.0 (Department of Biology, Arizona State University, Tempe, AZ, USA).

\section{Histopathological examinations}

For histological studies, the spleen, kidney, gill, intestine, and stomach were removed from moribund and surviving starry flounder and immediately fixed in 10\% neutral-buffered formalin. After fixation, standard histological procedures were used for tissue dehydration and paraffin embedding. Tissue sections were stained with hematoxylin and eosin (H\&E).
Stained sections were microscopically examined at magnifications ranging from $40 \times$ to $1000 \times(\mathrm{BX} 50 \mathrm{~F} 4$; Olympus, Tokyo, Japan).

\section{Results}

\section{Isolation and identification of iridovirus from starry flounder (SFIV0909)}

Diseased fish collected from the 2009 disease outbreak in Gyeongsangnam-do, Korea, were lethargic and showed anemia, petechiae of the gills, and enlargement of the spleen. The results of PCR using primer sets for diagnosing RSIV are shown in Fig. 1. Two specific PCR products were amplified from the spleen and kidney using the $4 \mathrm{~F} / 4 \mathrm{R}$ and IridoF/IridoR primers . However, the $1 \mathrm{~F} / 1 \mathrm{R}$ primer set, which was registered by OIE as RSIV-specific, did not amplify a product. The distilled water negative control showed no amplification. Parasites were absent in smears and wet mounts of infected fish, and bacteria were not consistently isolated from diseased fish.

\section{PCR amplification}

Results of RSIV PCR using three primer sets are shown in Fig. 1. Specific PCR products corresponding to the 568-bp fragment were amplified using the $4 \mathrm{~F} / 4 \mathrm{R}$ primer set and products corresponding to the 698-bp fragment were amplified using the Irido-F/Irido-R primer set from all diseased starry flounders. However, PCR using the $1 \mathrm{~F} / 1 \mathrm{R}$ primer set, and the negative control, did not result in amplification of a product.

\section{Analysis of the MCP nucleotide sequence}

To determine the genetic characteristics of the iridovirus from starry flounder (SFIV0909), a full-length open reading frame (ORF) of the MCP of SFIV0909 was amplified by PCR. The ORF of MCP was 1,362 bp in length and encoded a protein that contained 453 amino acids. The nucleotide sequence 


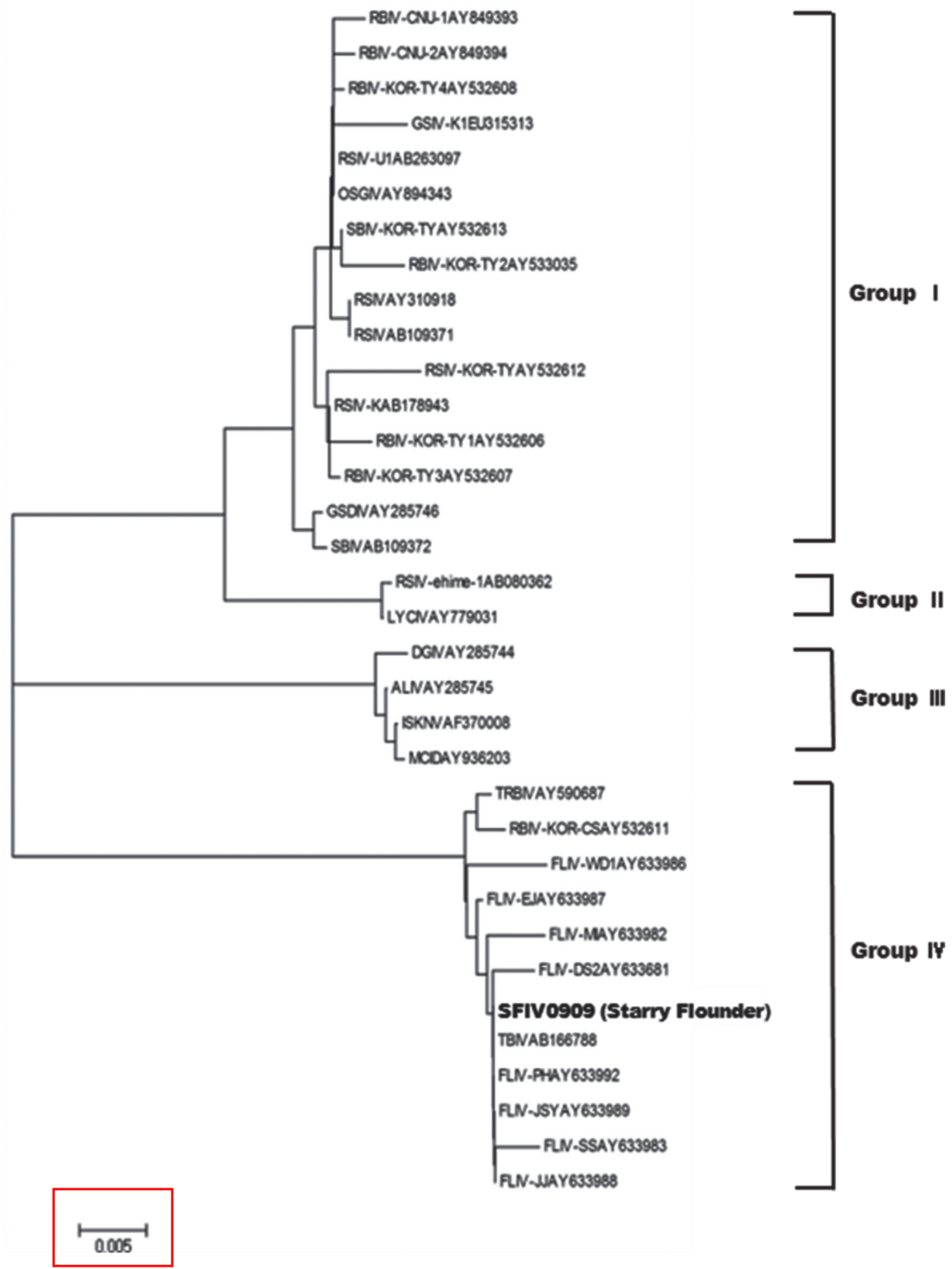

Fig. 2. Phylogenetic tree based on neighbor-joining analyses of the major capsid protein gene sequences of megalocytiviruses. Numbers at nodes indicate bootstrap confidence values (1,000 replications). GenBank accession numbers are given in parentheses. The detected starry flounder iridovirus is indicated in bold. 

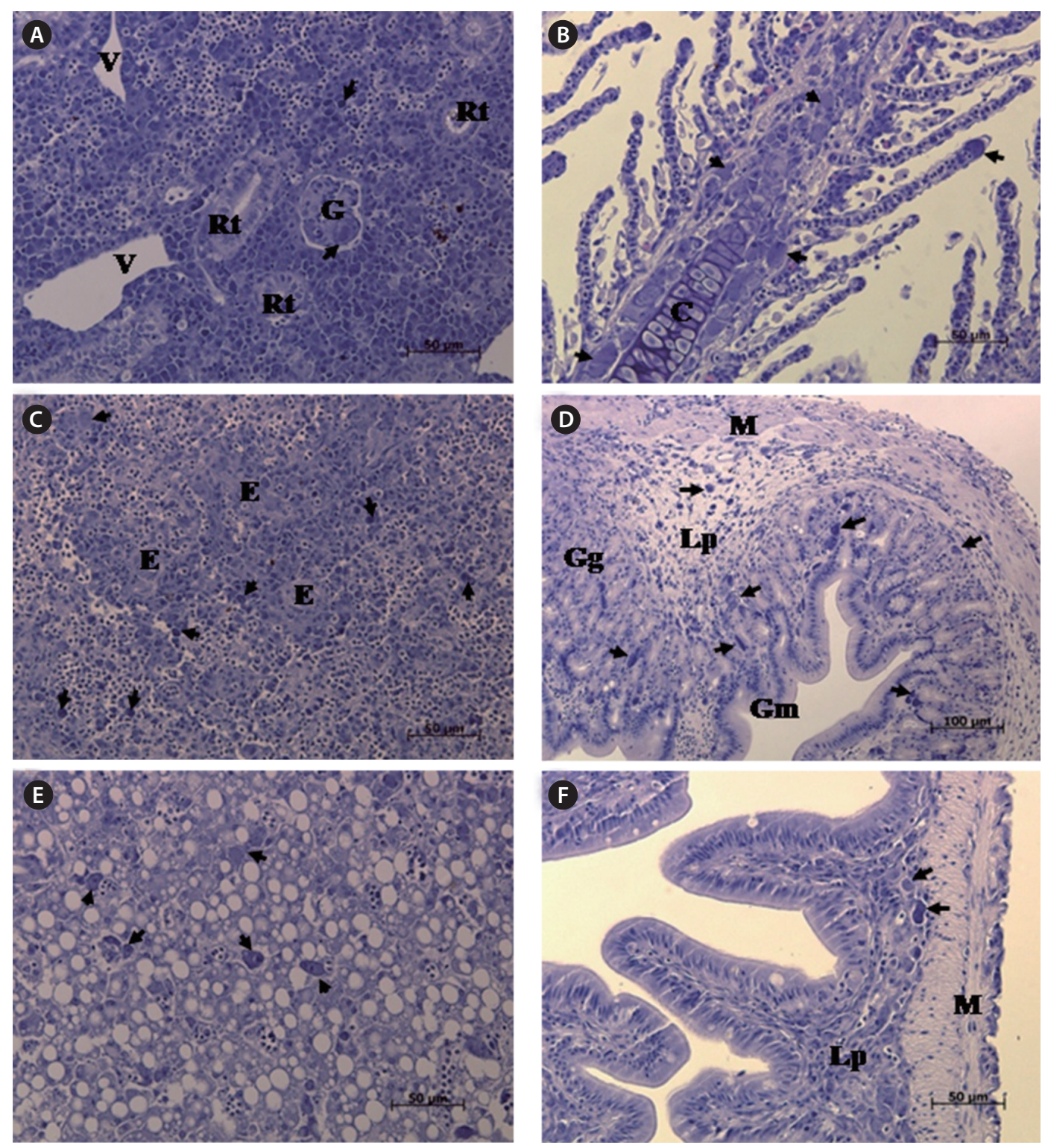

Fig. 3. Histopathological changes of naturally infected starry flounder Platichthys stellatus with iridovirus. Enlarged cells were observed in the kidney (A), gill (B), spleen (C), stomach (D), liver (E), and intestine (F) of infected starry flounder. C, cartilage; E, elipsoid ; G, glomerulus; Gg, gastric gland ; Gm, gastic mucosa; Lp, laminar propria ; $M$, muscle ; Rt, renal tube; $V$, vein .Black arrows indicate the enlarged cells (scale bars: $A-C, E, F=50 \mu m, D=100 \mu m$ ).

of SFIV0909 MCP was highly homologous to that of RSIV from other flatfish, such as turbot (urbot iridovirus [TBIV] AB166788 and TRBIV AY590687) and olive flounder (FLIVPH AY633992, FLIV-JSY AY633989, FLIV-M AY63398, etc.), and showed 94-100\% nucleotide sequence identity to the nucleotide sequences of 33 iridoviruses in GenBank. Based on the nucleotide sequence of MCP, a phylogenetic tree was constructed using a neighbor-joining algorithm (Fig. 2). The tree revealed that SFIV0909 was identical to TBIV (AB166788), with $100 \%$ homology clustered in group IV.

\section{Histopathological changes}

The most striking histopathological change in moribund starry flounder was the formation of basophilic enlarged cells in various tissues, including the spleen, kidney, gills, intestine, and stomach. In particular, the spleen displayed large numbers of enlarged cells within splenic pulps and sheathed tissue (Fig. 3). Severe, diffuse necrosis, accompanied by hemorrhage, was also evident in the spleen. 


\section{Discussion}

This report describes the identification and histopathological characterization of an iridovirus from diseased starry flounder. In Korea, megalocytiviruses were first reported as fish pathogens in 1998, when they caused mass mortality in rock bream, Oplegnathus fasciatus nationwide (Sohn et al., 2000; Do et al., 2004). This RBIV threatened the rock bream aquaculture industry. Subsequently, reports of occurrences of the RSIV in red sea bream Pagrus major, rockfish Sebastes schlegeli, and olive flounder Paralichthys olivaceus were published (Do et al., 2005). The ISKNV was also reported in freshwater ornamental fishes (Jeong et al., 2008) and the TBIV was found in the turbot, Scophthalmus maximus (Oh et al., 2006).

Although iridovirus infections have been documented in many countries and various fish species, iridoviruses associated with starry flounder have not to date been reported. This is probably because the history of starry flounder culture is short; cultivation of starry flounder has begun to expand only recently. In Korea, starry flounder culture started in 2005 with the production of 50,000 seed fish. The annual production of farmed starry flounder began at 17 metric tons in 2007 and increased to 158 metric tons in 2008, 341 metric tons in 2009, and 466 metric tons in 2010 (Statistics Korea, 2011). Starry flounder aquaculture is thought to have continued to develop rapidly in subsequent years because the species tolerates a wide range of salinities, endures crowded environments and exhibits rapid growth (Ding et al., 2010). Nevertheless, information about the diseases of starry flounder remains scarce. The only previous study of a disease outbreak in starry flounder reported an infection caused by Streptococcus parauberis (Cho et al., 2008), which was found to be highly virulent to starry flounder based on an $\mathrm{LD}_{50}$ of $4.2 \times 10^{3}-4.2 \times 10^{2} \mathrm{cfu} /$ fish at 7 days after intraperitoneal inoculation. Rhabdoviruses (Mork et al., 2004) and marine birnaviruses (Park et al., 2009) were also detected in starry flounder during a survey but did not cause disease outbreaks.

The outbreak in 2009 described in this study was the first to be documented in cultured starry flounder in Korea. In our study, we found that while no apparent bacterial infection was observed in moribund fish, SFIV0909 was detected in all diseased fish examined, which suggests that SFIV0909 was the etiological agent of the outbreak. Some unexpected results were also found in the PCR screening for RSIV because the specific primer set 1-F/1-R, which is recommended by OIE, did not amplify SFIV0909 from these starry flounder. This primer set is the most frequently used for the detection of RSIV; however, other researchers also failed to detect a fragment using the same forward primer1-F (Shi et al., 2010). They found that PCR of the spleens and kidneys of turbot with red body syndrome yielded no specific product, and reported detection by only transmission electron microscopy (TEM). Therefore, the results from any single primer set should be interpreted with caution.

Megalocytivirus isolates have been divided into four genotypes based on their MCP gene sequences (Dong et al., 2010). Megalocytiviruses in groups I and II are derived mainly from perciform fishes, whereas all megalocytiviruses from freshwater fishes fall into group III. Viruses in group IV are derived mainly from Pleuronectiformes in Korea and China. To date, olive flounder Paralichthys olivaceus and turbot Scophthalmus maximus were the only flatfishes in which megalocytivirus infections had been reported. Olive flounder iridovirus (FLIV) was first reported in Korea during an epizootic study in 2003 by Do et al. (Do et al., 2005). This study revealed that FLIV was a megalocytivirus that belongs to an unknown new genus distinct from RSIV and ISKNV. TBIV, however, has been investigated more extensively. In 1991, an infection associated with an iridovirus-like agent occurred in cultured turbot fry in Denmark, although the agent was detected by only electron microscopy and so could not be subjected to genetic analysis (Bloch and Larse, 1993). Subsequently, outbreaks of TBIV occurred in China (Shi et al., 2010) and Korea (Kim et al., 2005). Studies of these outbreaks revealed iridovirus-like particles by TEM, enlarged cells in the spleen and kidney, and detection of MCP genes by PCR. In addition, the spotted halibut Verasper variegatus is registered in OIE as a susceptible host species (World Organization of Animal Health, 2009).

In this study, SFIV0909 was found to belong to megalocytivirus genotype IV, along with most of the iridoviruses that infect turbot and olive flounder. This study also found $100 \%$ homology with TBIV (AB166788) from turbot in Korea (Oh et al., 2006), suggesting that the starry FLIV is identical to the agent found in turbot in Korea, and that it evokes the same pathogenicity in flatfishes. Histopathological changes in starry flounder were similar to those in the turbot, Scophthalmus maximus, infected with iridoviruses (Dong et al., 2010). Many enlarged cells were observed in the spleen and kidney but also in the liver, gill, stomach, and intestine of diseased starry flounder. However, further study of host susceptibility is needed to confirm this result because TBIV cross-infections in other cultured fish species have not been reported (Jeong et al., 2008). This study revealed that marine fish species are susceptible to TBIV isolated from turbot. After TBIV exposure of turbot, olive flounder, and rock bream, mortality in turbot reared at $25^{\circ} \mathrm{C}$ reached $100 \%$; however, no pathogenicity in olive flounder and rock bream was detected despite detection of TBIV by PCR at 26 days post-inoculation.

In conclusion, we detected for the first time a megalocytivirus, SFIV0909, in cultured starry flounder in Korea. Further work involving experimental inoculations of starry flounder with this virus should be completed to determine whether this iridovirus is the causative pathogen of the 2009 starry flounder outbreak. We found multiple indications that this virus was likely the causative agent, including the absence of other microbes and parasites in infected tissues and severe histopathological and cytopathological effects on various tissues 
and organs that were apparently induced by the virus. These results suggest that SFIV0909 causes serious systemic infection in starry flounder.

\section{Acknowledgements}

This study was supported by a grant for the National Fisheries Research and Development Institute (RP-2011-AQ-066).

\section{References}

Bian X, Zhang X, Gao T, Wan R, Chen S and Sakurai Y. 2010. Morphology of unfertilized mature and fertilized developing marine pelagic eggs in four types of multiple spawning flounders. Ichthyol Res 57, 343-357.

Bloch B and Larse JL. 1993. An iridovirus-like agent associated with systemic infection in cultured turbot Scophthalmus maximus fry in Denmark. Dis Aquat Org 15, 235-240.

Chinchar VG, Essbauer S, He JG., Hyatt A, Miyazaki T, Seligy V and Williams T. 2005. Family Iridoviridae. In: Virus Taxonomy, Classification, and Nomenclature of Viruses: Eighth Report of the International Committee on the Taxonomy of Viruses. Fauquet CM, Mayo MA, Maniloff J, Desselberger U and Ball LA, eds. Academic Press, San Diego, CA, US, pp. 145-161.

Chinchar VG, Hyatt A, Miyazaki T and Williams T. 2009. Family Iridoviridae: poor viral relations no longer. Curr Top Microbiol Immunol 328, 123-170.

Cho MY, Lee JI, Kim MS, Choi HJ, Lee DC and Kim JW. 2008. Isolation of Streptococcus parauberis from starry flounder, Platihthys stellatus Pallas. J Fish Pathol 21, 209-217.

Ding L, Zhang L, Wang J, Ma J, Meng X, Duan P, Sun L and Sun Y. 2010. Effect of dietary lipid level on the growth performance, feed utilization, body composition and blood chemistry of juvenile starry flounder (Platichthys stellatus). Aquac Res 41, 1470-1478.

Do JW, Moon CH, Kim HJ, Ko MS, Kim SB, Son JH, Kim JS, An EJ, Kim MK, Lee SK, Han MS, Cha SJ, Park MS, Park MA, Kim YC, Kim JW and Park JW. 2004. Complete genomic DNA sequence of rock bream iridovirus. Virology 325, 351-363.

Do JW, Cha SJ, Kim JS, An EJ, Park MS, Kim JW, Kim YC, Park MA and Park JW. 2005. Sequence variation in the gene encoding the major capsid protein of Korean fish iridoviruses. Arch Virol 150, 351-359.

Dong C, Weng S, Luo Y, Huang M, Ai H, Yin Z and He J. 2010. A new marine megalocytivirus from spotted knifejaw, Oplegnathus punctatus, and its pathogenicity to freshwater mandarinfish, Siniperca chuatsi. Virus Res 147, 98-106.

He JG, Weng SP, Zeng K, Huang ZJ and Chan SM. 2000. Systemic disease caused by an iridovirus-like agent in cultured mandarinfish,
Siniperca chuatsi (Basilewsky) in China. J Fish Dis 23, 219-222.

Hogstrand C, Ferguson EA, Galvez F, Shaw JR, Wenn NA and Wood CM. 1999. Physiology of acute silver toxicity in the starry flounder (Platichthys stellatus) in seawater. J Comp Physiol B 169, 461473.

Jeong JB, Kim HY, Jun LJ, Lyu JH, Park NG, Kim JK and Jeong HD. 2008. Outbreaks and risks of infectious spleen and kidney necrosis virus disease in freshwater ornamental fishes. Dis Aquat Org 78, 209-215.

Kawakami H and Nakajima K. 2002. Cultured fish species affected by red sea bream iridoviral disease from 1996 to 2000. Fish Pathol 37, 45-47.

Kim WS, Oh MJ, Jung SJ, Kim YJ and Kitamura S. 2005. Characterization of an iridovirus detected from cultured turbot Scophthalmus maximus in Korea. Dis Aquat Org 64, 175-180.

Lü L, Zhou SY, Chen C, Weng SP, Chan SM and He JG. 2005. Complete genome sequence analysis of an iridovirus isolated from the orange-spotted grouper, Epinephelus coioides. Virology 339, 81100.

Mork C, Hershberger P, Kocan R, Batts W and Winton J. 2004. Isolation and characterization of a rhabdovirus from starry flounder (Platichthys stellatus) collected from the northern portion of Puget Sound, Washington, USA. J Gene Virol 85, 495-505.

Oh MJ, Kitamura SI, Kim WS, Park MK, Jung SJ, Miyadai T and Ohtani M. 2006. Susceptibility of marine fish species to a megalocytivirus, turbot iridovirus, isolated from turbot, Psetta maximus (L.). J Fish Dis $29,415-421$

Park SH, Park MA and Cho MY. 2009. Phylogenetic analysis of marine birnavirus (MABV) isolated from cultured starry flounder Platichthys stellatus and olive flounder Paralichthys olivaceus in Korea. J Fish Pathol 22, 211-218.

Shi CY, Jia KT, Yang B and Huang J. 2010. Complete genome sequence of a megalocytivirus (family Iridoviridae) associated with turbot mortality in China. Virol J 7, 159.

Sohn SG, Choi DL, Do JW, Hwang JY and Park JW. 2000. Mass mortalities of cultured striped beakperch, Oplegnathus fasciatus by iridoviral infection. J Fish Pathol 13, 121-127.

Statistics Korea. 2011. Korean Statistical Information Service (KOSIS) database. Statistics Korea, Daejeon, KR, Accessed 25 Jun 2011, http://kostat.go.kr/wnsearch/search.jsp .

Wang CS, Chao SY, Ku CC, Wen CM and Shin HH. 2009. PCR amplification and sequence analysis of the major capsid protein gene of megalocytiviruses isolated in Taiwan. J Fish Dis 32, 543-550.

Williams T, Barbosa-Solomieu V and Chinchar VG. 2005. A decade of advances in iridovirus research. Adv Virus Res 65, 173-248.

World Organization of Animal Health. 2009. Manual of diagnostic tests for aquatic animals. World Organisation for Animal Health, Paris, FR, Accessed 25 Jun 2011, http://www.oie.int/en/internationalstandard-setting/aquatic-manual/access-online/. 